\title{
Patterns of Chemical Pesticide Use and Determinants of Self-Reported Symptoms on Farmers Health: A Case Study in Kano State for Kura Local Government Area of Nigeria
}

\section{Hussain Muhammad Isah ${ }^{1,2}$ Morufu Olalekan Raimi ${ }^{13^{*}} \quad$ Henry Olawale Sawyerr $^{1}$}

1. Department of Environmental Health Science, Kwara State University, Malete, Kwara State, Nigeria.

2. Kano State College of Health Sciences and Technology, Kano, Nigeria.

3. Department of Community Medicine, Environmental Health Unit, Faculty of Clinical Sciences, Niger Delta University, Wilberforce Island, Bayelsa State, Nigeria.

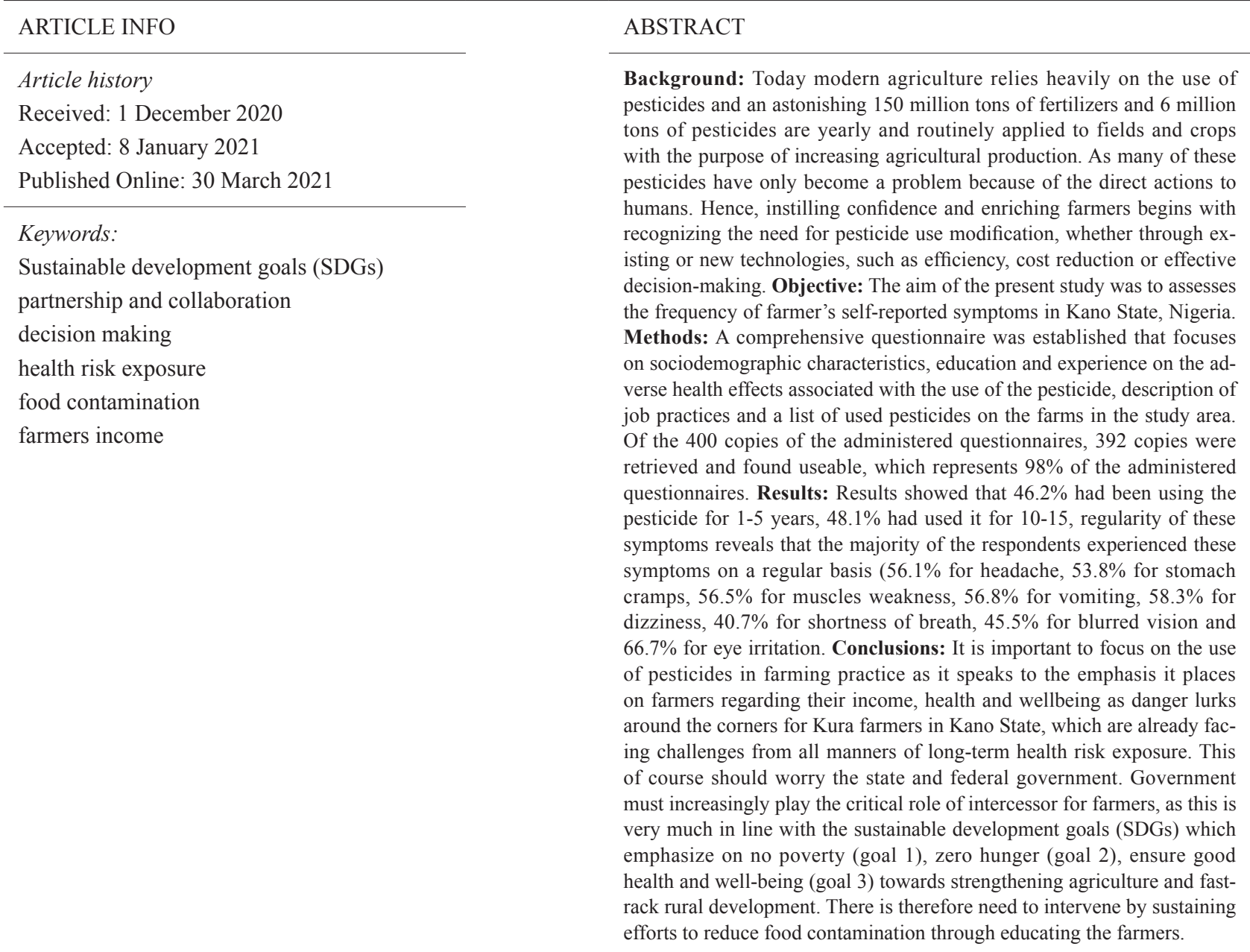

*Corresponding Author:

Morufu Olalekan Raimi,

ola07038053786@gmail.com; olamuf001@outlook.com 


\section{Introduction}

Over $65 \%$ of Nigerians living in rural areas have been largely neglected and denied access to modern healthcare services and other basic modern infrastructural necessities that are essential in order to maintain their health ${ }^{[1-4]}$. This is unacceptable, as a large part of the infrastructural underserved rural country's population provides the nation's food needs, including valuable export crops. Indeed, the agriculture significance to the development of Nigerian economy can't be over stressed in association to the attractive labour force. Rural residents face many repeated environmental threats related to agricultural every day risks, including pesticides, solvents and metals of occupational and environmental origin ${ }^{[5-13]}$. These anomalies are always a source of stress due to the combination of inorganic trace constituents' and the types of used pesticides in agricultural products and health practices. Longitudinal pesticides exposure has been reported to cause diseases like diabetes, cancer, neurological disorders and coronary heart disease ${ }^{[14]}$. Consequently, the pesticides which are very harmful to smallholder farmers institutes a typical trans-sectoral 'wicked problem' and concerns about the risks to human health from the risk of exposure to pesticides have increased significantly ${ }^{[15]}$. In addition, exposure to pesticides is one of the main significant threats to the health of farmers in the global south ${ }^{[16,17]}$. It is estimated that 25 million farmers are exposed to poisoning from acute pesticide yearly in the global south, making poisoning of pesticide a most significant worldwide health problem ${ }^{[17]}$. Globally, the commonly used pesticides by agricultural farmers include organophosphates, causing chronic chemical poisoning through enzymes inhibiting cholinesterase. This outcomes in excess nicotinic stimulation besides muscarinic receptors, leading to symptoms of chronic pesticide poisoning such as diarrhea, weakness, headache, vomiting, ataxia, dizziness, bradycardia, dyspnea, paralysis and finally death ${ }^{[18]}$.

Pesticides use in agricultural farming in Nigeria, particularly among Kano State farmers, has improved considerably over the past 20 years, as pesticides continue to be the pillar for agricultural control of pests and disease vectors. From the season's beginning to harvest, farmers are faced with a large amount of pesticides, which has potential to induce DNA damage ${ }^{[19]}$. The resulting mixture of pesticides may be more virulent and pose a greater risk to the public than individual pesticides, and raises concern on their human health impact ${ }^{[20]}$. However, it is problematic to determine the exact configuration of these combinations. Exposure to pesticides can lead to oxidative stress through the accumulation of unrestricted radicals that can accumulate in the cell, which in turn can damage nuclear acids and DNA protection and improve the immune system from the body defense mechanism ${ }^{[14]}$. In this case, oxidative stress may be explained by the use of trolox equivalent antioxidant capacity with peroxidation of serum lipids through thiobarbituric acid with reactive substances and by acquiring significant occupationally exposed information on populations ${ }^{[21,19]}$. Today, the study of pesticides is an important area of research on environmental pollution and several questions remain unanswered about the safety and toxicity of these products to human health and the environment. It is based on the above problem that this research sought to explore commonly used pesticides application and frequency of clinical symptoms of farmers on selected agricultural farmland in Kano State, Nigeria. The purpose of this research is to identify the impact of pesticides on health of farmers' through monitoring the prevalence of self-reported symptoms in Kano State. The focus on farmers is significant since from the season's beginning to harvest, farmers are often exposed to large amounts of pesticides, which has potential to induce DNA damage and pose a great risk to the exposed populations raising human health concerns. These health problems can affect health outcomes in years later. The knowledge, attitude and application of commonly used pesticides and the health indicators of many farmers in Kano State are essential to their health, wellbeing and future development. Thus, awareness helps to modify attitudes and behavior towards the pesticides. While significant research into understanding the health burden of chemical pesticide in Kano State has not been undertaken, a literature review revealed an absence in the research. The current study aims at contributing to the extant literature in this regard.

\section{Materials and Methods}

\subsection{Research Design}

The study adopted a descriptive survey research design. The descriptive survey design according to Gift and Obindah is a kind of research design in which the researcher collects data from a cross section of the study population in respect of variables. ${ }^{[1]}$ This design was considered appropriate for the study since it solicits information from a target group. The design involves collection and analyzing data gathered. Funmilayo et al., described descriptive survey design as a type of design to be employed when a study involves the use of questionnaire to seek the opinion of the respondents ${ }^{[2]}$. Funmilayo et al., added that the descriptive survey type of design is the most convenient way to obtain real facts and figures in which the results of 
the analyses will be used for decision making or generalization. This research design is considered suitable for this study considering the fact that this study's primary objective centers on the assessment of commonly used pesticides application and frequency of farmers' self-reported health symptoms from selected agricultural farmland in Kano State, Nigeria. The choice of a descriptive survey design was premised on its value and facility in addressing the research problem raised in the study.

\subsection{The Study Area}

Location

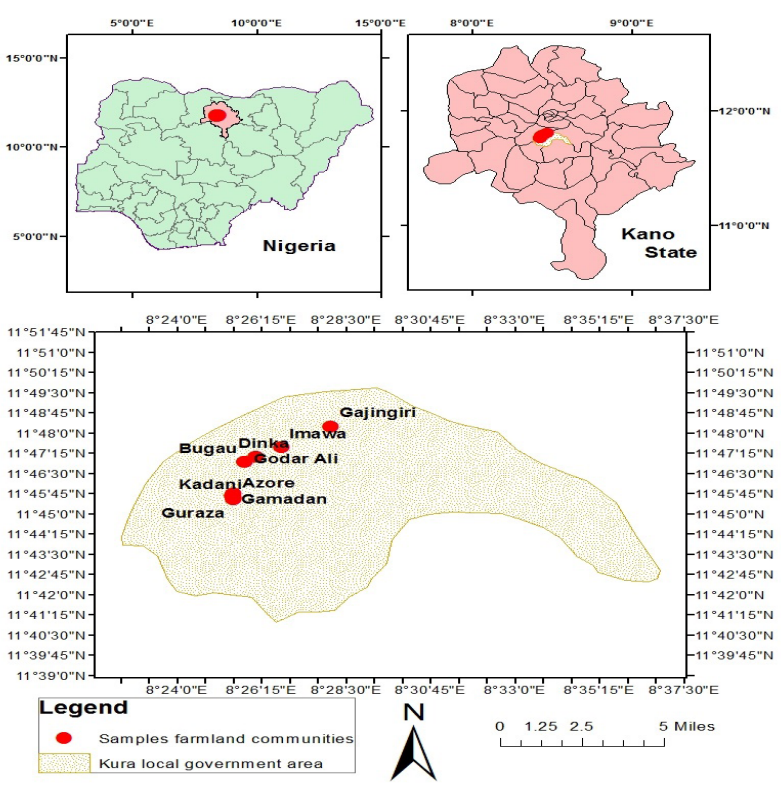

Figure 1. Map of Kano State showing the location of the Study Area in Nigeria.

Adapted from Isah et al., ${ }^{[49]}$ [DOI: 10.5281/zenodo.4008682.] and Olalekan et al., ${ }^{[50]}[10.15406 /$ ahoaj.2020.04.00170]

Kano State is located between latitude $13^{\circ} \mathrm{N}$ and $11^{\circ} \mathrm{N}$ and longitude $8^{\circ} \mathrm{W}$ and $10^{\circ} \mathrm{E}$ (Figure 1). It is approximately 840 kilometers away from the Sahara Desert. Kano has a mean height of around $472.45 \mathrm{~m}$ above sea level. Kano State has 44 provinces: "Ajingi, Albasu, Bagwai, Bebeji, Bichi, Bunkure, Dala, Dambatta, Dawakin Kudu, Dawakin Tofa, Doguwa, Gabasawa, Garko, Garun Mallam, Gaya, Gezawa, Gwale, Gwarzo, Kabo, Karaye, Kibiya, Kiru, Kumbotso, Kura, Kunchi, Madobi, Makoda, Minjibir, Kano Municipal, Nassarawa, Rimin Gado, Rogo, Shanono, Sumaila, Takai, Tarauni, Tsanyawa, Tudun Wada, Tofa, Warawa and Wudil".

Kano State has an overall land area of 20,760sq kilometers with $9,383,682$ population of inhabitants (2006 provisional result) ${ }^{[1]}$. Kano temperature is always between $33^{\circ} \mathrm{C}$ and $15.8^{\circ} \mathrm{C}$ even though it occasionally reaches $10^{\circ} \mathrm{C}$ during harmattan season. Kano has two seasons, including 4 to 5 months of rain and a prolong dry spell usually from the month of October through April. The air masses movement from South West maritime, extending out of the Atlantic Ocean with the impact of the rainy season, starting from May to September. The start and duration of the rainy season varied between the northern and southern parts of Kano State. In the southern State of Kano, Riruwai last six (6) months beginning early May through late September. Northern parts of Kano State go from the month of June to early September ${ }^{[1]}$. Average precipitation ranges from $63.3 \mathrm{~mm}+48.2 \mathrm{~mm}$ in May and $133.4 \mathrm{~mm}+$ $59 \mathrm{~mm}$ during the month of August. Air masses from the tropical maritime move from Southwest to North, which regulates the weather of Kano State all through the rainy season. Moisture from the Atlantic Ocean is being transported through the air masses. This humidity is absorbed once its forced to increase by means of convection or over a barrier of highland's or a mass of air; and it came like rain. Peak period happens when the sun sets across West Africa amongst March through June. The dry spell begins in the month of October then lasts until April of next year. Low temperatures are usually experience around this time as the sun faces Southern Hemisphere as the desiccating continental mass of air movement which extends through the Sahara, while blowing through the Northeast and carry the harmattan dust with it,implying the period of harvest ${ }^{[1]}$.

\subsection{Population and Sample Size}

The study population comprised farmers in Kura local government area of Kano State, North West, Nigeria. Available statistics, based on the 2006 population census, showed that Kura has a total population of 143094 people and $80 \%$ of them were farmers ${ }^{[24]}$. Hence, the population of the farmers was estimated to be 114475 . The population of the study was projected in 2018 using population growth rate of $2.47 \%$ as provided by the Nigeria population commission ${ }^{[25]}$. The projected population was obtained using the following equation:

$$
\text { Equation 1: } P_{t}=P_{0}(1+r)^{t}
$$

where, $\mathrm{P}_{\mathrm{t}}$ is the projected population, $\mathrm{P}_{\mathrm{o}}$ was the population in 2006 (114 475), $\mathrm{r}$ is the population growth rate $(2.47 \%=0.0247)$, and $t$ is the number of years (12).

$$
P_{t}=P_{0}(1+r)^{t}=114475\left(1+\frac{2.47}{100}\right)^{12}
$$


$=114475(1+0.0247)^{12}$

$=114475(1+0.0247)^{12}=114475(1.0247)^{12}=114475(1.3402)=153417$

Hence, the projected population of 153417 farmers in Kura of Kano State was estimated.

Sample size

A sample size of 399 farmers in Kura was estimated using an equation described by Yamane ${ }^{[26]}$. Sample size was estimated as:

$$
\text { Equation 2: } N=\frac{N}{1+N(e)^{2}}
$$

where, $\mathrm{n}$ is the sample size to be determined, $\mathrm{e}$ is the level of significance, and $\mathrm{N}$ is the population size.

$$
\begin{aligned}
& N=\frac{N}{1+N(e)^{2}}, \quad N=153417, \quad e=0.05 \\
& N=\frac{153417}{1+153417(0.05)^{2}} \\
& N=\frac{153417}{1+153417(0.0025)}=\frac{153417}{1+383.5425}=\frac{153417}{384.5425}=398.9
\end{aligned}
$$

\section{9}

\subsection{Sampling Techniques}

The study adopted a multi-stage random sampling technique in the sample selection precess. In the first stage of the sampling, random sampling was used to sample 10 villages out of the total of 26 villages in Kura local government area. Randomization was done through balloting. The selected villages were Sarkin Kura, Gamadan, Azore, Kadani, Guraza, Imawa and Godar Ali. During the second stage of sampling, a random sample was selected to select farmers from 10 villages. To give each of the selected villages a uniform number of farmers, the sample size was divided equally across the 10 selected villages and a sample of 40 farmers were selected from each of the villages.

\subsection{Instruments for Data Collection}

Researchers developed a questionnaire entitled "Prob- abilistic Assessment of Self-Reported Symptoms on Farmers Health" that was used in data collection. It was comprised of 25 sections which focus on different demographics including sex, marital status, age, educational qualification, farming experience, farm size, land ownership status, use of pesticides, common used pesticides, effect of pesticides, health problem associated with the exposure to pesticide use and the effect of the pesticide's application on the environment. The study also assesses the safety measures farmers use to control pesticides and the behaviors when using pesticides.

\subsection{Validity of Instrument}

The research questionnaire was presented to experts for validation. Copies of the questionnaire were presented to three experts, two from Environmental Health Science, Kwara State University and one expert in research and statistics (statistician). These experts were required to examine the validity of the research instrument (questionnaire) in terms of language, clarity and content in line with the purpose of the study, research questions and the hypotheses it would measure.

\subsection{Method of Data Collection}

To facilitate data collection, the researchers employed four research assistants. Two of the research assistants helped in the administration of the data. The research assistants were properly briefed on how to administer the questionnaire. The questionnaire was administered within a four-week periods. Each of the research assistant covered two communities while the researcher also covered two communities. Of the 400 copies of the administered instruments, 392 copies were retrieved and found useable, representing $98 \%$ of the administered questionnaire.

\subsection{Methods of Data Analysis}

Entered questionnaires information were rechecked for quality assurance in an Excel sheet before analysis was done. All submission requests from the semi-structured and comprehensive questions were summarized from all respondents using statistics that are analyzed descriptively such as simple percentages and frequency distribution were used to analyse the demographics of the respondents and to answer the research questions. Also, some vital results of the analysis were presented using pictorial representation like bar chart, cluster bar charts and other forms of pictorial representation. To enhance data analysis and computation of results, version 20.0 of the SPSS was used. 


\section{Results}

\subsection{Demographics of the Respondents}

Distribution of Respondents by Sex

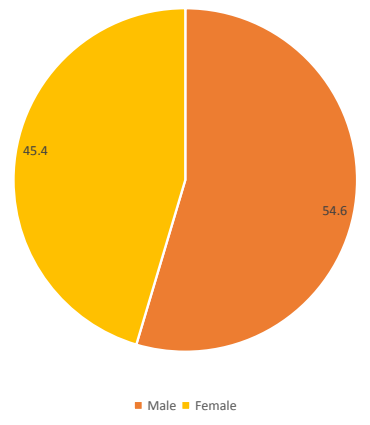

Source: Field Survey, 2019

Figure 2. Distribution of Respondents by Sex

Figure 2 presents the demographics of the respondents. Result of the distribution of the respondents based on sex reveals that $54.6 \%$ of the farmers were male and $45.4 \%$ were female.

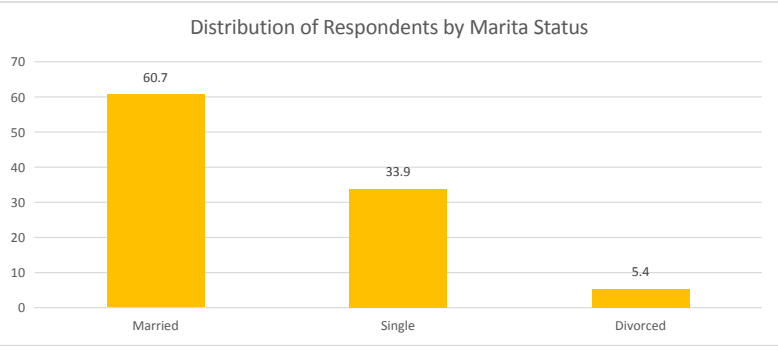

Source: Field Survey, 2019

Figure 3. Distribution of Respondents by Marita Status

Result also shows that $60.7 \%$ were married, $33.9 \%$ were single and $5.4 \%$ were divorced.

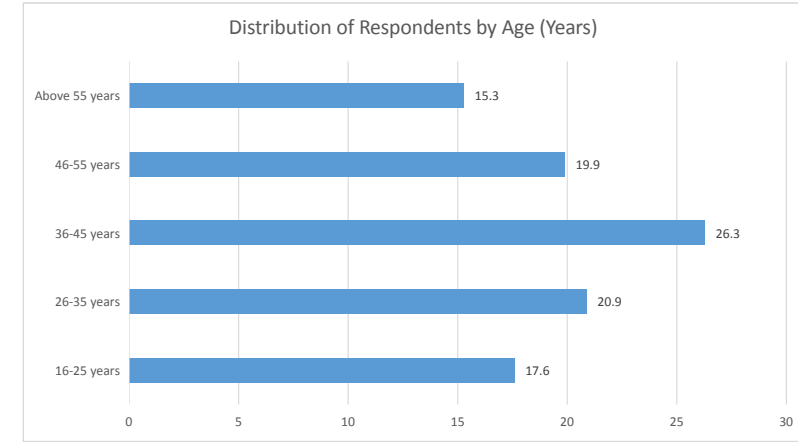

Source: Field Survey, 2019

Figure 4. Distribution of Respondents by Age (Years)

The distributions of the respondents based on age were as follows: $17.6 \%$ were between ages $16-25$ years, $20.9 \%$ were between 26-35 years, 26.3\% were between $36-45$ years, $19.9 \%$ were between $46-55$ years while the remain- ing $15.3 \%$ of the respondents were above 55 years.

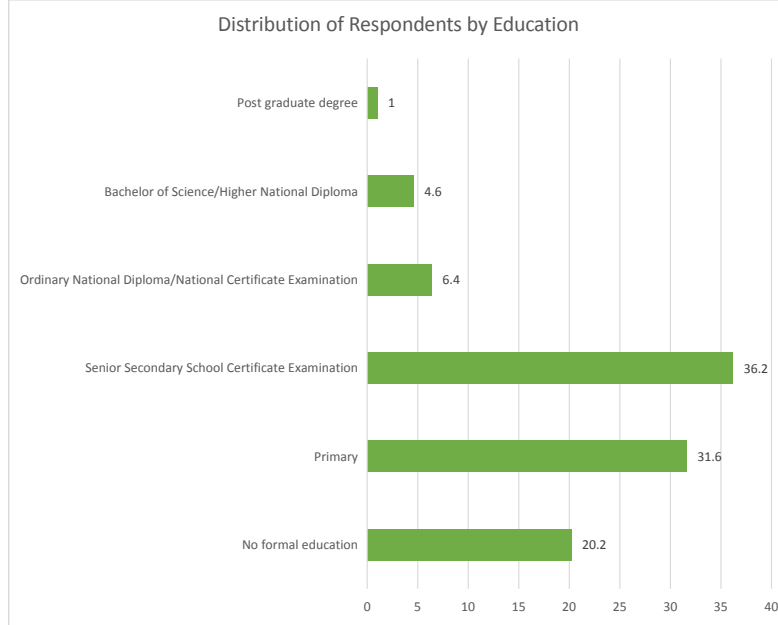

Source: Field Survey, 2019

Figure 5. Distribution of Respondents by Education

In terms of their educational qualification, $20.2 \%$ of the farmers had no formal education, $31.6 \%$ had primary education, $36.2 \%$ of the farmers had secondary education, $6.4 \%$ were OND/NCE holders, $4.6 \%$ were B.Sc/HND holders while $1.0 \%$ had postgraduate degrees.

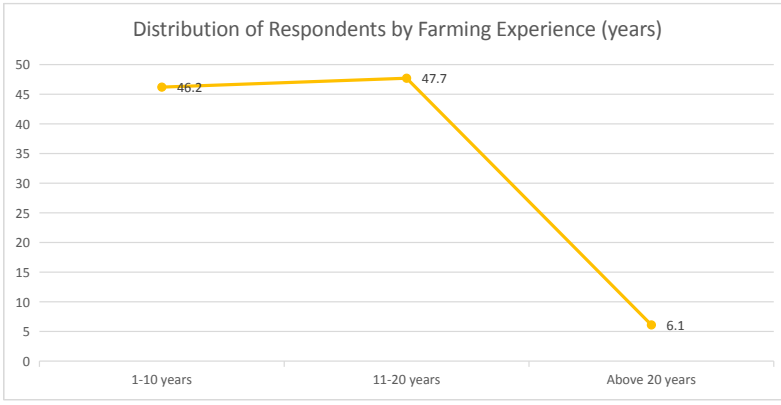

Source: Field Survey, 2019

Figure 6. Distribution of Respondents by Farming Experience (years)

Result also shows that $46.2 \%$ of the respondents had 1-10 years of farming experience, $47.7 \%$ had $11-20$ years of farming experience and $6.1 \%$ of the farmers had above 20 years of farming experience.

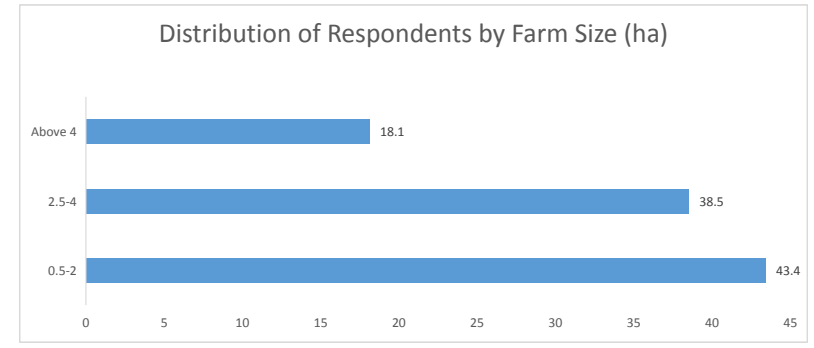

Source: Field Survey, 2019

Figure 7. Distribution of Respondents by Farm Size (ha)

The distribution of the farmers based on farm size reveals that $43.4 \%$ of the respondents had $0.5-2.0$ hect- 
ares of land, 38.5\% had 2.5-4.0 hectares of land and only $18.1 \%$ of the farmers had above 4 hectares of land.

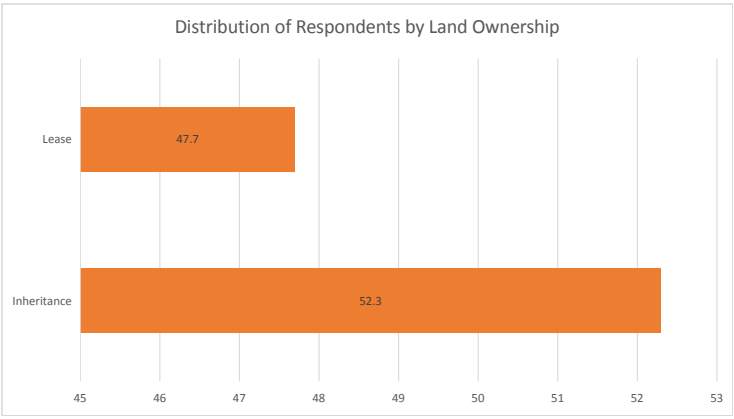

Source: Field Survey, 2019

Figure 8. Distribution of Respondents by Land Ownership

In terms of land ownership status, $52.3 \%$ of the farmers acquired their land through inheritance while $47.7 \%$ of the farmers acquired their lands through leasing.

In Table 1 are the World Health Organization (WHO) classifications of the pesticides presented. The pesticides most commonly used (mainly pyrethroids, phenylamide and s-metolachlor compounds) by small scale farmers in Kura are categorized by WHO as moderately hazardous and slightly hazardous ${ }^{[27]}$. The classification of the pesticides shows that insecticides and herbicides are mostly used group, followed by fungicides $(31.2 \%)$. However, $12 \%$ of the other (unidentified), pesticides were used multi-purposely. The insecticides used belonged to the chemical groups of pyrethroids, carbamates and organochlorines. The herbicides belonged to the groups of triazines, aryloxyphenoxypropionate and chloroacetanilide.

Table 1. Products Reported as Used by Farmers in Kura

\begin{tabular}{|c|c|c|c|}
\hline $\begin{array}{c}\text { Type of pesticide used } \\
\text { (trade name) }\end{array}$ & Active ingredient & Main use & $\begin{array}{c}\text { Chemical } \\
\text { Hazardous Class } \\
\text { (WHO) }\end{array}$ \\
\hline Apron Plus & $\begin{array}{c}\text { Metalaxyl } \\
\text { (phenylamide) }\end{array}$ & Fungicide & II \\
\hline Atrazine & Triazines & Herbicides & III \\
\hline Polythrine & $\begin{array}{l}\text { Cypermethrin } \\
\text { (pyrethroids) }\end{array}$ & Insecticides & II \\
\hline Sevin & $\begin{array}{c}\text { Carbaryl } \\
\text { (carbamate) }\end{array}$ & Insecticides & II \\
\hline Thiodan & $\begin{array}{c}\text { Endosulfan (or- } \\
\text { ganochlorine) }\end{array}$ & Insecticide & II \\
\hline Fusilade & $\begin{array}{c}\text { Fluazifop-p- } \beta u t y l \\
\text { (aryloxyphenoxy- } \\
\text { propionate) }\end{array}$ & Herbicides & III \\
\hline Primextra & $\begin{array}{c}\text { S-Metolachlor } \\
\text { (chloroacetanilide) }\end{array}$ & Herbicides & $\begin{array}{c}\text { Has no known } \\
\text { WHO hazard } \\
\text { classification }\end{array}$ \\
\hline \multicolumn{4}{|l|}{ Others/unidentified } \\
\hline $\begin{array}{l}\text { Note: I, extremely } \\
\text { hazardous; IV, unlik }\end{array}$ & $\begin{array}{l}\text { hazardous; II, mode } \\
\text { ely to present acute } \\
\text { dition. }{ }^{[27]}\end{array}$ & $\begin{array}{l}\text { tely hazardo } \\
\text { zards under }\end{array}$ & $\begin{array}{l}\text { us; III, slightly } \\
\text { normal use con- }\end{array}$ \\
\hline
\end{tabular}

\subsection{Answering of Objective Questions}

Table 2 shows that $41.4 \%$ of the respondents who complained of pesticides related problems had headache, $39.4 \%$ had stomach cramps, $46.5 \%$ complained of muscle weakness, $37.4 \%$ complained of vomiting, 36.4\% complained of dizziness, $27.3 \%$ complained of shortness of breath, $11.1 \%$ complained of blurred vision while $54.5 \%$ complained of eye irritation. Results of the analysis of the regularity of these symptoms reveals that the majority of the respondents experienced these symptoms on a regular basis: $56.1 \%$ for headache, $53.8 \%$ for stomach cramps, $56.5 \%$ for muscles weakness, $56.8 \%$ for vomiting, $58.3 \%$ for dizziness, $40.7 \%$ for shortness of breath, $45.5 \%$ for blurred vision and $66.7 \%$ for eye irritation (see figure 9 below).

Table 2. Symptoms and Frequency of Symptoms Among Farmers who use Pesticides and Experience Some Effects

\begin{tabular}{ccccc}
\hline & \multicolumn{2}{c}{ Frequency of self-reported symptoms } & \\
\hline $\begin{array}{c}\text { Health related self- } \\
\text { reported symptoms }\end{array}$ & $\begin{array}{c}\text { Regularly } \\
\mathbf{n}(\%)\end{array}$ & $\begin{array}{c}\text { Occasionally } \\
\mathbf{n}(\%)\end{array}$ & $\begin{array}{c}\text { Rarely } \\
\mathbf{n}(\%)\end{array}$ & Total \\
\hline Headache & $23(56.1)$ & $13(31.7)$ & $5(12.2)$ & $41(41.4)$ \\
Stomach cramps & $21(53.8)$ & $14(35.9)$ & $4(10.3)$ & $39(39.4)$ \\
Muscles weakness & $26(56.5)$ & $15(32.6)$ & $5(10.9)$ & $46(46.5)$ \\
Vomiting & $21(56.8)$ & $12(32.4)$ & $4(10.8)$ & $37(37.4)$ \\
Dizziness & $21(58.3)$ & $13(36.1)$ & $2(5.6)$ & $36(36.4)$ \\
Shortness of breath & $11(40.7)$ & $11(40.7)$ & $5(18.5)$ & $27(27.3)$ \\
Blurred vision & $5(45.5)$ & $2(18.2)$ & $4(36.4)$ & $11(11.1)$ \\
Eye irritation & $36(66.7)$ & $13(24.1)$ & $5(9.3)$ & $54(54.5)$ \\
\hline
\end{tabular}

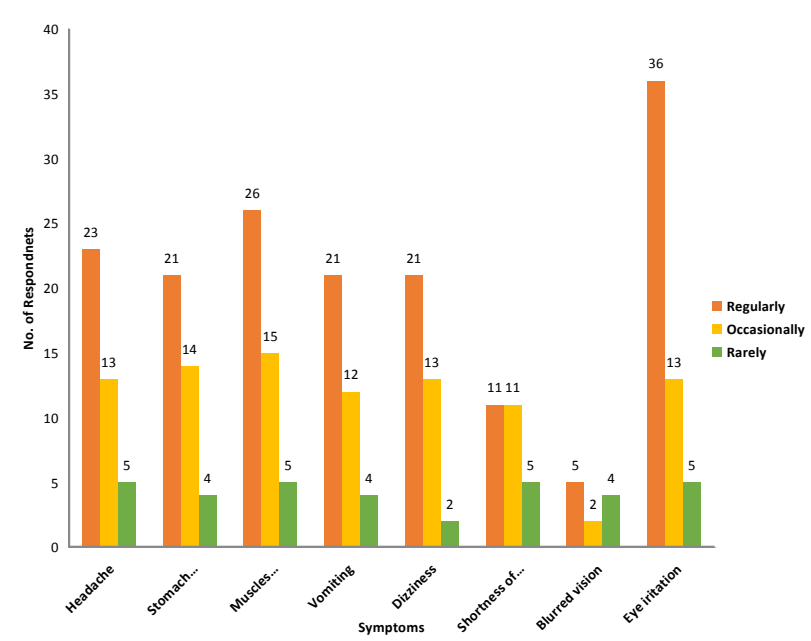

Figure 9. Cluster bar chart showing the distribution of the symptoms of pesticide use and frequency of self-reported symptoms in Kura Local Government Area (L.G.A). Kano State, Nigeria. 


\section{Discussion}

\subsection{A Review of the Samples In Question}

Before the statistical analysis's outcomes were observed, the reviewed samples needed to be ascertained through the specific population the outcomes were generated. The socio-demographic characteristic, including sex, marital status, age, farm size, land ownership, levels of education and farmers farming experience concerning handling of pesticide is revealed in Figure 2 to 8 . There are observed significant difference between the gender distribution of respondents in their classification. The male proportion of respondents was $54.6 \%$, somewhat larger than the number of female respondents. The majority of male farmers participants may perhaps remain the outcome of males having more farmland access than females. It might also happen because farming is labor-intensive, and women may struggle to meet the needed effort to cultivate significant crops. This view is supported through Abubakar et al. who found that most male farmers $93 \%$, while $7 \%$ were female, and Bhandari and others who indicates that around $90 \%$ of farmers interviewed were males ${ }^{[28,29]}$. But is contrary to the study conducted by Prince et al. who found less male farmers $(21.7 \%)$ than female $(78.3 \%)$, and Pornpimo et al., who state that most Thai agricultural workers in their study were women $(60 \%)$ and that the agricultural workers characteristics in this research varied in terms of farm type ${ }^{[30,31]}$. The present study was different from the World Bank report of 2007 with comparable number of female and male agricultural workers in Southeast Asia in 2007 ${ }^{[32]}$, indicating that agricultural labour force constitutes 60 to 80 percent of females in emerging countries. The report postulated that the recent increase in the number of women agricultural farmers are due to drivers of the economic that force more men to migrate to urban centers where their services are needed in the industrial or other money economy jobs; though, it may perhaps remain that women are more willing than men to be subjects in their study. However, as demographics shift and turn out to be more technologically advanced, adolescents are realizing that farm produces due to hard work and high cost depends on uncertain income because of the dependence on crop prices and weather patterns. It is interesting to note that there has been a shift in the people involved in agriculture in Kano State. Gradually adolescents leave the rural areas and migrate to the urban centres to find jobs in the service or manufacturing segment. They arrived home to provide agricultural assistance in the farm and in the family garden once required. The study participants were young people between the ages of 36 and 45. Meaning that the mean age reflects the positive attitude of labour in agricultural production. While, this is very useful on productivity for positive effects, as adolescent farmers are very active and tends to use novel technologies. These findings are consistent with the study done by Bhandari et al. who found that $47 \%$ were between the age range of 30-49 years and 50 years old were more than $23 \%{ }^{[29]}$. This Bhandari study was an outcome of stratified sampling technique in order to minimise its impacts on the sizes of small cell by tilting the frequency distributions in Bhandari study. Similarly, this view is contrary to the study conducted by Prince et al. who found that the 46-55 years $(34.8 \%)$ was the largest group in the study who engage in farming activities ${ }^{[30]}$. In our study farmers' education levels ranged from no formal education to a doctorate, the majority of farmers had an education level of SSCE or its equivalent $(36.2 \%)$, whereas the least had a post graduate degree (1\%). This shows that the educational level of the responding farmers is strongly influencing, since most of them have at least a secondary education. Education revolutionize human attitudes. It supports people to know their environment to solve numerous snags. Meanwhile, these results are similar to those of Bhandari et al. who estimated that around $30 \%$ of farmers are uneducated and the remaining farmers have different education levels, which include primary $(23 \%)$, junior secondary $(20 \%)$, secondary $(19 \%)$ and college $(8.7 \%)^{[29]}$. Research shows that farmers who are educated are better positioned to accept and understand the health effects of pesticides information, likened to those with low education and that human capital studies have also shown that farmer education plays a remarkable role in allocation and skills development of farmers ${ }^{[3,1]}$. However, this view is contrary to the study conducted by Islam et al. who found that the majority of respondents $(51.7 \%)$ had no education knowledge ${ }^{[34]}$. They could neither read nor write and $35.0 \%$ of the participants had basic education. Approximately $11.7 \%$ of the participants have completed secondary education, and only $1.7 \%$ of the participants have completed higher school ${ }^{[34]}$. Similarly, Prince et al. found that the $48.9 \%$ of the farmers had no formal education ${ }^{[30]}$. Hanif also stated that farmers who are educated were extra careful with the use of pesticide and its environmental impact ${ }^{[35]}$. A significantly higher proportion of the participants in the present study were married $(60.7 \%)$ compared to participants who were single (33.9\%). This finding is similar to that of Bammeke, who argued in his study, that people who take on agricultural practices were married ${ }^{[36]}$. Similarly, this view is consistent with Prince et al., who found that $25.0 \%$ of farmers are single while $69.6 \%$ were married and $5.4 \%$ were divorced ${ }^{[30]}$. This suggests that married respondents were more likely to experience the problem than those who responded from other groups, and therefore the example was a demonstrative model of the community 
configuration Our results showed that $46.2 \%$ of the farmers had between 1 and 10 years of experience while $47.7 \%$ had between 11 and 20 years' experience and $6.1 \%$ have above 20 years of experience. This indicated that the individuals engaged in farming activities were experienced in farming. This view is contrary to the study by Prince et al. In which it was noted that $72.8 \%$ of the agricultural farmers had between 1 and 10 years' experience while $27.2 \%$ had between 11 and 20 years' experience ${ }^{[30]}$. Also, Islam et al. found that the majority of respondents $(60.0 \%)$ had farming experience between $16-20$ years, whereas $23.3 \%$ of the respondents had farming experience of $10-15$ years, $6.7 \%$ of the farmers had 21-25 years' experience in farming, $6.7 \%$ of the farmers had obtain 25-26 years of agricultural farming knowledge, and only $3.3 \%$ of the farmers had $36-40$ years' of farming experience ${ }^{[34]}$. Research by Islam et al. shows that experienced farmers have a good knowledge of agriculture and they know a lot about the effects of pesticides on the environment ${ }^{[37]}$. The size of farm varied from one individual to the other and farm size is measured in ha in the area studied. The highest percentage (43.4\%) of farmers had a farm size of $0.5-2 \mathrm{ha}$, while $38.5 \%$ respondents had between $2.5-4$ ha, $18.1 \%$ respondents had above 4 ha.

\subsection{Effects of Pesticides Use on Farmers' Health by Monitoring the Frequency of Self-Reported Symptoms in Kano}

Health is one of the most significant components of the human capital for rural people in emerging countries. The study participants highlighted the potential risks of the use of pesticide and their adverse effects on environment and health. The farmers associate the potential symptoms from the exposure of pesticides linked to the acute poisoning toxicological effects. This could be as a result of majority of them were knowledgeable and several of them had experienced some of these mentioned symptoms. Results of the analysis of the regularity of these symptoms reveals that the majority of the respondents experienced these symptoms on a regular basis: $56.1 \%$ for headache, $53.8 \%$ for stomach cramps, $56.5 \%$ for muscles weakness, $56.8 \%$ for vomiting, $58.3 \%$ for dizziness, $40.7 \%$ for shortness of breath, $45.5 \%$ for blurred vision and $66.7 \%$ for eye irritation. These results are not in tandem with Bhandari et al. study which showed that nearly all agricultural farmers alleged having symptoms of acute health after using pesticide ${ }^{[29]}$. In the study, self-reported toxicity is the most often symptoms linked to pesticides, which include headache $(73.8 \%)$, skin irritation $(62.3 \%)$, eye irritation (32.8\%), weakness (22.4\%) and muscle pain (19.1\%). His results are in agreement with previous research in Nepal and Vietnam ${ }^{[38,39]}$.
Conversely, this result is not consistent with the research of Maria et al., which shows the majority of common symptoms include cephalea (77 persons or $51.7 \%$ of 149 intoxicated patients) trailed by dizziness (48 people) and vomiting (42 people) ${ }^{[40]}$. Below half of the farm employees identified cephalea ( 29 people) considered this sign by way of physical appearance of pesticides intoxication (self-examination intoxication). On one hand, over $50 \%$ of all people who report diarrhea and those who report dizziness, vomiting and stomach discomfort identified themselves as intoxicated. Further signs identified by the farm employees in their study included blurred vision, loss of appetite, burning face, fatigue, body itching, fever, ringing in the ears and spots on the body. In addition, less than half of the 149 people who identify signs after pesticides use identified themselves highly intoxicated through these products. Cases of self-reported intoxication with higher incidence among younger workers have been reported by Yassin et al. and recommended that this people could express themselves through the interviews better ${ }^{[41]}$. Some recent studies have shown an applicator with illness or symptoms leading to visiting the health care provider who may not be possible to remember this incident than other who ensured not to seek care $^{[42,43]}$. Symptoms identified in this study include dizziness, cephalea (headache), abdominal pain and vomiting are specific pesticides exposure, such as the organophosphorus and Carbamate insecticides ${ }^{[44,45]}$. Similarly, the finding are not consistent with a study conducted by Gurung and Kunwar ${ }^{[46]}$, which showed $96 \%$ of the respondents knew skin irritation as a poisoning symptoms from pesticides use, which is not consistent with the study of Lekki et al., which shows $66 \%$ of the respondents had awareness regarding skin irritation ${ }^{[47]}$. The findings of Gurung and Kunwar, showed that $98 \%$ and $96 \%$ of the respondents knew dizziness and headache as poisoning symptoms of pesticides use in the nervous system ${ }^{[46]}$. This is contrary to what happened in this current research, as the findings of Lekei et al., is not consistent with the study which shows $49 \%$ had awareness regarding dizziness and $66 \%$ about headache ${ }^{[47]} .84 \%$ of respondents were aware of nausea as poisoning symptoms of pesticides use in gastro-intestinal system which is not consistent with Lekei et al., which shows 34\% had awareness regarding nausea ${ }^{[47]}$. The high frequency of the regularity of self-reported symptoms among farmers in Kano State reveals that the majority of the respondents experienced these symptoms on a regular basis. This is less than what was stated in Kenya, due to the prevalence of episodes of poisoning $(61.1 \%$ of agricultural workers reported four (4) or more prior poisonings) ${ }^{[48]}$. These data most probably indicate non-severe condition because they go unidentified in the absence of an Acute Pesticides Poison- 
ing (APP) surveillance program since they do not appear at health center. These APP cases are closely monitored by the community on the basis of self-reporting systems. The above re-affirmed pesticides exposure to be one of the main remarkable occupational risks for farmers in the global south and to identify the risks associated with pesticides use and develop pesticides safe methods while handling pesticide. However, most farmers in the study area do not have formal education and without any form of training, so they must be exposed to training and education on the dangers of pesticides usage. This is in tandem with Prince et al. who found that most of the agricultural workers were ignorant, and only an insignificant cluster are educated/ literate ${ }^{[30]}$. It was also shown that $48.9 \%$ of the agricultural workers are illiterate and lack knowledge on the appropriate use of agrochemicals, they merely use through learning from their seniors, which possibly will not always be right. Additionally, controlling pesticide usage through regulatory system of proffered is well-known. Studies has shown that residual pesticide are a major concern for consumers that fears frequently when they buy farmed products and community concern around pesticides in their milieu, that their effects on human health is steadily increasing.

\section{Summary and Conclusion}

Small holder farmers using highly toxic pesticides, particularly from the global south has become a trans-sectoral definitive 'wicked problem'. Wicked snags are an issue of effective advertising marketing methods, which are hard-hitting to accomplish due to variances amongst development partners in media outreach, response and understanding by smallholder farmers to the problem ranging from 0.2 to 2.0 hectares. For several small holder farmers, pesticides that are cheap and hazardous in the short term have been effective and profitable thereby improving agricultural production, wages for temporary contract workers, and the survival of family. This study highlights the potential high risks of pesticides exposure to human and the environment in a certain rural community in Kano State. This highlights the potential to exacerbate serious public health snag that could be prevalent in the state. This result finding has remarkable policy implications in adding to sound advocacy interventions particularly for policy makers in Kano State. Firstly, it is important to inform farmers about the pesticide's effects on human health and to improve farmers' education about issues of pesticide safety and pest management. The Nigerian government must do its best to convince agricultural farmers to lessen the pesticides use. Disseminating a more detailed information about pest management and associated information, including better education, extension services for agricultural farmers and training. Subsequently, iden- tifying alternative sources of chemical pesticide by means of lessening the farmer's health risk, which is also of grave significant in Nigeria. Pesticides substitution and improving seed quality and resistance to host plants can lead to less use of pesticide without reducing the yield of crop. Lastly, whereas the integrated pest management (IPM) concept has received robust support, the IPM expansion technology is, after all, a major issue for millions of households in Nigeria. Henceforth, government ought to do its best to facilitate the development of short-term local pesticide spraying services, although the use of pesticides may still be necessary, however, the development of IPM strategies would reduce, if not completely stamp out pesticides use in the long term. Also, a crucial pillar in the considerations of pesticides is the "precautionary principle" and ought to be an important guide in policy making regarding pesticides safety. Therefore, the study put forward the following ideas for recommendations: Endorsement of sound farming practices that is organic and ecological in nature, holistic and suitable for local farming practices that remain undisruptive to the social, economic, gender and cultural considerations, Governments should provide literary education on all level of organic agriculture and in relevant research centres, Promote agriculture production patterns that have minimal environmental footprints, Regulating the dependence of agricultural farmers on artificial products like the use of harmful pesticides to the milieu, Advocating for community awareness on pesticide safety measures through approaches including the community, legislators, private sector, decision makers and the administrators, Promoting and supporting agricultural practices that encourage biodiversity preservation and guarantees wholesome food and quality products that are good, Requires that farmers should be represented throughout the boards that are associated with agriculture pesticides and Provide appropriate risk criteria for evaluation and necessitate that such evaluation be carried out in Nigeria and not overseas.

\section{Study limitation}

The chief limitation of this research is the use of self-report to describe the case. Even though it is frequently applied in several countries, this method is probable to overemphasize the problem triggered by exposure to pesticides. Also, long-term studies will require to providing additional evidence to the causality of associations assessed in this research. Another snag may be related to the incentives (financial or otherwise) for research respondents, based on past understanding of farmers' in large foreign financial research projects. The inability to pay compensation could have prevent some farmers from partaking. In contrast, farmers with previous pesticide histo- 
ries of poisoning are more likely to participate. However, the magnitude of the non-participation was low so was improbable to make an immense change to the findings. Moreover, participants knowledge of pesticides is poor, which include the failure to identify pesticide product by its trade name or common name and classification, which could have contributed to poisoning agents misreporting or improved the quantity of poisonings as a result of unknown agents. Therefore, the classification snag due to WHO Class I and II pesticides could be noticeably underreported. What the farmers show about the symptoms of the disease cannot be recalled if the details are forgotten. Even with having some hazards awareness and exposure routes, farmers will not be able to combine all the signs with specific exposure. As a result, this may have resulted to an underestimation of the reported pesticide linked with association of poisoning symptoms and products handled.

\section{Competing interests}

We affirm that we have no conflict of interest that may be alleged as prejudicing the impartiality of the study reported. This researcher did not receive special assistance from government, not-for-profit sectors or commercial institutions.

\section{Consent}

All the authors announced that they had received written notice from the participants.

\section{Ethical approval}

Ethical approval for the study was sought and gotten from the Institutional Review Board of the Kwara State University. Permission to carry out the research as well as written consent was also obtained from the farmers after explaining the purpose of the study to them. This was done by meeting the Kano State Farmers Association. Furthermore, the purpose of the study was again explained to participants before completing the self-administered questionnaire. Participants were assured confidentiality and informed that their participation was voluntary. Respondents were advised not to indicate their names on the questionnaire in order to ensure the confidentiality and anonymity of the information provided.

\section{References}

[1] Isah H.M (2019) Risk Assessment Associated with Pesticide Application on Selected Agricultural farmland in Kano State, Nigeria. MSc thesis from the Department of Environmental Health Sciences, School of Allied Sciences, Kwara State University.
[2] Olalekan RM, Oluwatoyin OA, Olawale SH, Emmanuel OO, Olalekan AZ (2020) A Critical Review of Health Impact Assessment: Towards Strengthening the Knowledge of Decision Makers Understand Sustainable Development Goals in the Twenty-First Century: Necessity Today; Essentiality Tomorrow. Research and Advances: Environmental Sciences. 2020(1): 72-84. DOI: 10.33513/RAES/2001-13. https://ospopac.com/journal/environmental-sciences/ early-online.

[3] Ajayi F.A, Raimi M.O, Steve-Awogbami O.C, Adeniji A.O, Adebayo P.A (2020) Policy Responses to Addressing the Issues of Environmental Health Impacts of Charcoal Factory in Nigeria: Necessity Today; Essentiality Tomorrow. Communication, Society and Media. Vol 3, No 3. DOI: https://doi.org/10.22158/ csm.v3n3p1. http://www.scholink.org/ojs/index.php/ csm/article/view/2940.

[4] Gift RA, Olalekan RM, Owobi OE, et al (2020). Nigerians crying for availability of electricity and water: a key driver to life coping measures for deepening stay at home inclusion to slow covid-19 spread. Open Access Journal of Science. 2020;4(3):69-80. DOI: 10.15406/oajs.2020.04.00155.

[5] Raimi M. O and Sabinus C. E. (2017) An Assessment of Trace Elements in Surface and Ground Water Quality in the Ebocha-Obrikom Oil and Gas Producing Area of Rivers State, Nigeria. International Journal for Scientific and Engineering Research (Ijser): Volume 8, Issue 6, July Edition. ISSN: 2229-5518.

[6] Morufu Raimi and Clinton Ezekwe (2017) Assessment of Trace Elements in Surface and Ground Water Quality (2017) LAP Lambert Academic Publishing. Mauritius. ISBN: 978-3-659-38813-2. www.omniscriptum.com.

[7] Raimi M. O, and Sabinus C. E (2017) Influence of Organic Amendment on Microbial Activities and Growth of Pepper Cultured on Crude Oil Contaminated Niger Delta Soil. International Journal of Economy, Energy and Environment. Vol. 2, No. 4, 2017, pp. 56-76. DOI: 10.11648/j.ijeee.20170204.12.

[8] Olalekan, R. M., Omidiji, A. O., Nimisngha, D., Odipe, O. E. and Olalekan, A. S. (2018). Health Risk Assessment on Heavy Metals Ingestion through Groundwater Drinking Pathway for Residents in an Oil and Gas Producing Area of Rivers State, Nigeria. Open Journal of Yangtze Gas and Oil, 3, 191-206. https://doi.org/10.4236/ojogas.2018.33017.

[9] Sawyerr O. H, Odipe O. E, Olalekan R. M, et al. (2018) Assessment of cyanide and some heavy metals concentration in consumable cassava flour "lafun" across Osogbo metropolis, Nigeria. MOJ Eco 
Environ Sci. 2018;3(6):369-372. DOI: 10.15406/ mojes.2018.03.00115.

[10] Odipe O. E, Raimi M. O, Suleiman F (2018). Assessment of Heavy Metals in Effluent Water Discharges from Textile Industry and River Water at Close Proximity: A Comparison of Two Textile Industries from Funtua and Zaria, North Western Nigeria. Madridge Journal of Agriculture and Environmental Sciences. 2018; 1(1): 1-6.doi: 10.18689/mjaes-1000101.

[11] Henry O. S, Morufu O. R, Adedotun T. A \& Oluwaseun E. O (2019) Measures of Harm from Heavy Metal Pollution in Battery Technicians' Workshop within Ilorin Metropolis, Kwara State, Nigeria. Scholink Communication, Society and Media ISSN 2576-5388 (Print) ISSN 2576-5396 (Online) Vol. 2, No. 2, 2019 www.scholink.org/ojs/index.php/csm. DOI: https://doi.org/10.22158/csm.v2n2p73.

[12] Olalekan R. M, Dodeye E. O, Efegbere H. A, Odipe O. E. Deinkuro N. S, Babatunde A and Ochayi E. O (2020) Leaving No One Behind? Drinking-Water Challenge on the Rise in Niger Delta Region of Nigeria: A Review. Merit Research Journal of Environmental Science and Toxicology (ISSN: 2350-2266) Vol. 6(1): 031-049 DOI: 10.5281/zenodo.3779288.

[13] Raimi M. O, Adio Z. O, Odipe O. E, Timothy K. S, Ajayi B. S \& Ogunleye T. J (2020) Impact of Sawmill Industry on Ambient Air Quality: A Case Study of Ilorin Metropolis, Kwara State, Nigeria. Energy and Earth Science Vol. 3, No. 1, 2020. URL: http:// dx.doi.org/10.22158/ees.v3n1p1. www.scholink. org/ojs/index.php/ees ISSN 2578-1359 (Print) ISSN 2578-1367 (Online)

[14] Mostafalou, S. and Abdollahi, M. (2017) Pesticides: an update of human exposure and toxicity. Arch. Toxicol., 91, 549-599.

[15] da Silva, J., Moraes, C. R., Heuser, V. D., et al. (2008) Evaluation of genetic damage in a Brazilian population occupationally exposed to pesticides and its correlation with polymorphisms in metabolizing genes. Mutagenesis, 23, 415-422.

[16] Wesseling C, De Joode BVW, Ruepert C, León C, Monge P, Hermosillo H, Partanen L.J (2001). Paraquat in developing countries. Int J Occup Environ Health; 7:275-86.

[17] Thundiyil JG, Stober J, Besbelli N, Pronczuk J (2008). Acute pesticide poisoning: aproposed classification tool. Bull World Health Organ; 86:205-9.

[18] Kapka-Skrzypczak L, Cyranka M, Skrzypczak M, Kruszewski M (2011). Biomonitoringand biomarkers of organophosphate pesticides exposure - state of the art. Ann Agric Environ Med; 18:294-303.

[19] Alves, J. S., da Silva, F. R., da Silva, G. F., et al.
(2016) Investigation of potential biomarkers for the early diagnosis of cellular stability after the exposure of agricultural workers to pesticides. An. Acad. Bras. Cienc., 88, 349-360.

[20] Bolognesi, C. and Holland, N. (2016) The use of the lymphocyte cytokinesis-block micronucleus assay for monitoring pesticide-exposed populations. Mutat. Res., 770, 183-203.

[21] Koureas, M., Tsezou, A., Tsakalof, A., Orfanidou, T. and Hadjichristodoulou, C. (2014) Increased levels of oxidative DNA damage in pesticide sprayers in Thessaly Region (Greece). Implications of pesticide exposure. Sci. Total Environ., 496, 358-364.

[22] Gift RAA, Obindah F (2020). Examining the influence of motivation on organizational productivity in Bayelsa state private hospitals. Open Access J Sci.2020;4(3):94-108. DOI: 10.15406/ oajs.2020.04.00157.

[23] Funmilayo A. A, Robert O. T, Olalekan R. M, Okoyen E, Tuebi M (2019). A study of the context of adolescent substance use and patterns of use in yenagoa local government, Bayelsa State, Nigeria. MOJ Addiction Medicine and Therapy. 2019;6(1):25-32. DOI: 10.15406/mojamt.2019.06.00142.

[24] Ayodele, O.J. (2016). Economic analysis of irrigated rice production in Kura local government area of Kano state, Nigeria. An M.Sc Dissertation, Department of Agricultural Economics and Rural Sociology, Ahmadu Bello University, Zaria.

[25] NPC (2006). National Population Commission. Nigeria: Abuja.

[26] Yamane, T. (1967). Statistics: An Introductory Analysis, 2nd Ed., New York: Harper and Row.

[27] World Health Organization (WHO) (2009): The WHO Recommended Classification of Pesticides by Hazard and Guidelines to Classification. Geneva, Switzerland.

[28] Abubakar M., Mala M. A., Mumin A., Zainab T. \& Fatima A. A (2015) Perceptions of Environmental Effects of Pesticides use in Vegetable Production by Farmers along River Ngadda of Maiduguri, Nigeria. Journal of Agriculture and Environmental Sciences. June 2015, Vol. 4, No. 1, pp. 212-215 ISSN: 23342404 (Print), 2334-2412 (Online) URL: http://dx.doi. org/10.15640/jaes.v4n1a26.

[29] Bhandari G, Atreya K, Yang X, Fan L, Geissen V. Factors affecting pesticide safety behaviour: The perceptions of Nepalese farmers and retailers. Sci Total Environ. 2018 Aug 1;631-632:1560-71.

[30] Prince E. Kainga, Temitope A. Miller, Timothy T. Epidi (2016) Assessment of Awareness of Benefits and Hazards Posed by Agricultural Pesticides to 
Farmers in Selected Communities of Bayelsa State, Nigeria. International Journal of Research in Agriculture and Forestry. Volume 3, Issue 2, February 2016, PP 32-40 ISSN 2394-5907 (Print) \& ISSN 23945915 (Online).

[31] Pornpimo Kongtip, Noppanun Nankongnab, Redeerat Mohaboo-npeeti, Sasivimol Bootsikeaw, Kiattisak Batsungnoen, Chalalai Hanchenlaksh, Mathuros Tipaya-Mongkholgul and Susan Woskie (2018) Difference among Thai Agricultural Workers Health working conditions and pesticides use by farm type. Annals of work exposure and health. Vol. 62, No.2, 169-181. Doi: 10.1093/annweh/wxx099.

[32] World Bank. (2007) Gender issues in agricultural labor overview. Available at http://siteresources.worldbank.org/ INTGENAGRLIVSOUBOOK/Resources/ Module8.pdf. Accessed October 2017.

[33] Gomes J, Lioyd O. L, Revitt D. M (1999) The influence of personal protection, environmental hygiene and exposure to pesticides on the health of Immigrants farm workers in a desert country. Int Arch Occup Environm. Health; 72(1):40-45.

[34] Islam M. A, Hossain M. T, Khatun M, Hossen M. S (2015) Environmental impact assessment on frequency of pesticide use during vegetable production. Progressive Agriculture 26: 97-102, 2015. ISSN: $1017-$ 8139.

[35] Hanif MA (2000). Comparative Analysis Between FFS and Non-FFSs Farmers Environment Awareness. MS Thesis, Department of Agriculture Extension Education, BAU, Mymensingh.

[36] Bammeke TOA (2003) Accessibility and utilization of agricultural information in the economic empowerment of women farmers in South Western Nigeria. University of Ibadan.

[37] Islam M. M, Motiur B, Akanda MGR (1998). Farmers awareness on the environmental Pollution. Bangladesh Journal of Trading and Development, 11(1 \&2): $33-38$.

[38] Atreya K (2008a) Probabilistic assessment of acute health symptoms related to pesticide use under intensified Nepalese agriculture, Int. J. Environ. Health Res. 18, 187-208.

[39] Dasgupta S, Meisner C, Wheeler D, Xuyen K, Thi Lam N (2007) Pesticides Poisoning of farm workers-implications of blood test results from Victnam. Int. J. Hyg. Environ. Health. 210, 121-132.

[40] Maria Celina P, Recena Eloisa D. Caldas, Dario X Pires, Elenir Rose J. C, Pontec (2006) Pesticides exposure in Cutturama, Brazil - Knowledge, attitude and practices. Environmental Research. Doi: 10.1016/J.envres.2006.01.007.
[41] Yassin, M. N., Abu Mourad, T. A., Safi, J. M., (2002) Knowledge, attitude, practice and toxicity symptoms associated with pesticides use among farm workers in the Gaza strip. Occup. Environ. Med. 59, 387-394.

[42] Keim, S. A., Alavanja M.C.R (2001) Pesticides use by persons who reported a high pesticides exposure event in the agricultural health study. Environ. Res. $85,256-259$.

[43] Lichtenberg, E. Zimmerman R (1999) Adverse health experiences, environmental attitudes, and pesticides usage behaviour of farm operator. Risk Anal. 19, 283-294.

[44] Smit L.A., Van-Wendel-de-Joode, B.N Heederik, D. Peiris-John, R.J., Van der Hoek, W (2003) Neurological Symptoms among Sri-Lankan Farmers Occupationally exposed to acetylcholinesterase-inhibiting insecticides. Am J. Ind. Med. 44, 254-264.

[45] Kamel, F., Engel, L.S, Gladen, B.C. Hoppin J.A, Alavanja M.C Sandler D. P (2005) Neurologic symptoms in licensed private pesticides applicators in the agricultural health study. Environ. Health Perspect. $113,877-882$.

[46] Gurung S, Kunwar M. (2017) Awareness Regarding Health Effects of Pesticides Use Among Farmers in A Municipality of Rupandehi District. Journal of Universal College of Medical Sciences. Vol.05 No.02 Issue 16.

[47] Lekei EE, Ngowi AV, London L (2014). Farmers' knowledge, practices and injuries associated with pesticide exposure in rural farming villages in Tanzania. BMC Public Health; 14:389. doi: 10.1186/14712458-14-389.

[48] Ohayo-Mitoko G, Kromhout H, Simwa JM, Boleij J, Heederik D (2000): Self-reported symptoms and inhibition of acetyl cholinesterase activity among Kenyan farm workers. Occup Environ Med, 57:195-200.

[49] Isah H. M, Raimi M. O, Sawyerr H. O, Odipe O. E, Bashir B. G, Suleiman H (2020) Qualitative Adverse Health Experience Associated with Pesticides Usage among Farmers from Kura, Kano State, Nigeria. Merit Research Journal of Medicine and Medical Sciences (ISSN: 2354-323X) Vol. 8(8) pp. 432447, August, 2020. DOI: 10.5281/zenodo.4008682. https://meritresearchjournals.org/mms/content/2020/ August/Isah\%20et\%20al.htm.

[50] Olalekan RM, Muhammad IH, Okoronkwo UL, Akopjubaro EH (2020). Assessment of safety practices and farmer's behaviors adopted when handling pesticides in rural Kano state, Nigeria. Arts \& Humanities Open Access Journal. 2020;4(5):191-201. DOI: 10.15406/ahoaj.2020.04.00170. 